\title{
A Study on Customer Churn in the Telecommunications Industry
}

\author{
Jaanvee Sawant \\ NMIMS' Kirit P. Mehta School of Law, Mumbai, Maharashtra, India.
}

CITATION: Sawant, Jaanvee (2020), "A Study on Customer Churn in the Telecommunications Industry”, MERC Global's International Journal of Management, Vol. 8, Issue 3, pp. 121-124.

ARTICLE HISTORY: Submitted: April 5, 2020, Revision received: May 10, 2020, Accepted: May 25,2020

\begin{abstract}
ARTICLE TYPE: Review paper
ABSTRACT

The purpose of this research paper is to showcase the significance of understanding and analysing the role of customer churn and its impact on the telecommunications industry holistically and focuses on the factors affecting customer churn decision and the retention strategies applied to the target customers. Churn analysis is one of the common applications used to predict the behaviour of the customers who are most likely to discontinue the provided service. Hence, it's essential to examine the customer churn as it plays a pivotal role in determining the measures to be undertaken to ensure customer retention in the telecommunications industry. To successfully retain customers who would if not abandon the business, retention experts and marketers must be able to firstly, predict in advance which customers are going to churn through churn analysis and secondly, know which marketing behaviour will have the utmost retention impact on every customer. Armed with this data, a great proportion of customer churn can be eliminated. The paper showcases the significance of understanding and analysing the role of customer churn and its impact on the sales, customer services and the telecommunications industry as a whole. It focuses on the factors affecting customer churn decision along with the retention strategies applied to the target customers.
\end{abstract}

KEYWORDS: Customer churn, Telecommunications industry, Retention.

\section{BIBLIOGRAPHY}

1. $\mathrm{Au}, \mathrm{Tom}$; Li, Shaomin and Ma, Guangqin (2003), “Applying and evaluating models to predict customer attrition using data mining techniques, Journal of Comparative International Management, Vol. 6, Issue 1, pp. $10+$.

2. Bose, I. and Chen, X. (2009), "Hybrid Models Using Unsupervised Clustering for Prediction of Customer Churn", Journal of Organisational Computing and Electronic Commerce, Vol. 19, Issue 2, pp. 133-151.

3. Dass, Rajanish and Jain, Rumit (2011), An Analysis on the factors causing telecom churn: First Findings, AMCIS Proceedings.

4. Dechant, Andrea; Spann, Martin and Becker, Jan U. (2018), "Positive Customer Churn", Journal of Service Research, Vol. 22, Issue 1, DOI: 10.1177/1094670518795054.

5. Goodman, J. A. (2014), Customer experience 3.0: high-profit strategies in the age of techno service, American Management Association, New York.

6. Gursoy, Tugba Simsek (2010), “Customer Churn analysis in telecommunication sector", Journal of the School of Business Administration, Vol. 39, No. 1, pp. 35-49.

7. Hashmi, Nabgha; Butt, Naveed Anwer and Iqbal, Muddesar (2013), "Customer Churn Prediction in Telecommunication: A Decade Review and Classification”, IJCSI International Journal of Computer Science Issues, Vol. 10, Issue 5, pp. 271-282.

8. Huan, Bingquan; Kechadi, Mohand Tahar and Buckley, Brian (2012), "Customer churn prediction in telecommunications", Expert Systems with Applications, Vol. 39, pp. 1414-1425.

9. Hudaib, A.; Dannoun, R.; Harfoushi, O.; Obiedat, R. and Faris, H. (2015), "Hybrid Data Mining Models for Predicting Customer Churn", International Journal of Communications, Network and System Sciences, Vol. 08, Issue 05, pp. 91-96. 
10. Jonathan, Burez and Poel, Dirk Van den (2006), "CRM at a Pay-TV Company: Using Analytical Models to Reduce Customer Attrition by Targeted Marketing for Subscription Services," Expert Systems with Applications, Vol. 32, Issue 2, pp. 277-288.

11. Kamalraj, N. and Malathi, A. (2013), "A Survey on Churn Prediction Techniques in Communication Sector", International Journal of Computer Applications, Vol. 64, Issue 5, pp. 0975-8887.

12. Kaur, Manpreet and Mahajan, Prerna (2015), "Churn Prediction in Telecom Industry Using R", International Journal of Engineering and Technical Research, Vol. 3, Issue 5, pp. 46-53.

13. Lejeune, M. A. (2001), "Measuring the impact of data mining on churn management", Internet Research, Vol. 11, Issue 5, pp. 375-387.

14. McKinsey (2020), Reducing Churn in Telecom through Advanced Analytics, available at: https://www.mckinsey.com/industries/technology-media-and-telecommunications/our-insights/reducingchurn-in-telecom-through-advanced-analytics, accessed on February 25, 2020.

15. Umayaparvathi, V. and Iyakutti, K. (2016), Attribute selection and Customer Churn Prediction in telecom industry, International Conference on Data Mining and Advanced Computing. 